\title{
Development of Multimedia Lectora Inspire Integrated Problem Based Learning on Carbohydrate Topic for Department of Agrotechnology Students
}

\author{
Nuraini \\ Postgraduate Program of Chemistry Education \\ Universitas Negeri Medan \\ Medan, Indonesia \\ Ainidalimunthe.ad@gmail.com
}

\author{
Saronom Silaban \\ Lecture in Postgraduate Program of Chemistry Education \\ Universitas Negeri Medan \\ Medan, Indonesia
}

\author{
Murniaty Simorangkir \\ Lecture in Postgraduate Program of Chemistry Education \\ Universitas Negeri Medan \\ Medan, Indonesia
}

\begin{abstract}
A standard learning material can be designed as a learning media to facilitate the students with complete information from the appropriate sources and can be accessed anytime and be able to facilitate students to learn independently. This study aimed to provide a multimedia Lectora Inspire integrated Problem Based Learning (PBL) on carbohydrate topic to be used as a learning media in the teaching and learning activities for students of Department Agrotechnology at Universitas Medan Area in academic year of 2018/2019. This study of research is Research and Development method that uses ADDIE. The samples were totally selected and divided into two groups. Development of multimedia Lectora Inspire integrated PBL in experimental class I while the learning media that used in Department of Agrotechnology used in experimental class II. Data were analyzed using descriptive method and statistical analysis with independent sample t-test. The experimental class has fulfilled the requirement for normality and homogeneity test. The results showed that: (1) the learning media used in Department of Agrotechnology on carbohydrate topic is eligible to use but needs to be developed; (2) multimedia that has been developed by using Lectora Inspire integrated PBL on carbohydrate topic is very eligible to be used as a learning media in accordance with the standart of SNPT eligibility (3.75), the eligibility of interactive computer media (3.48), and the eligibility of PBL (3.38); (3) students achievement in experimental class I was found to be higher than in the experimental class $\mathrm{II}(0,74>$ 0,64).
\end{abstract}

Keywords-agrotechnology; carbohydrate; lectora inspire; multimedia; problem based learning

\section{INTRODUCTION}

Implementation of National Qualifications Framework (in Indonesia Kerangka Kualifikasi Nasional Indonesia, KKNI) as the basic of competence standard has been the teaching and learning paradigm to adopt competence-based curriculum in university refer to SNPT (Standar Nasional Pendidikan
Tinggi). The students are required to processes adequate knowledge, skills and good character to adjust themselves to the relevant sector for life [1].

The development of science and technology has brought changes in almost every aspect of life [2]. Teaching innovations have been proven effective for enhancing learning activities to facilitate the development of students' cognitive skills, and to provide a pleasant learning environment for example learning innovation using technology [1]. Standard learning materials can be designed as a learning medium to facilitate students with complete information from appropriate sources and can be accessed at anytime and can facilitate students to learn independently [3].

Learning media that has been applied in learning is expected the learning process, achieve learning objectives in order to improve student achievement, and motivate them towards subject matter. The development of instructional media by utilizing Information and Communication Technology (ICT) in schools is an excellent choice, especially if implemented in the form of comuter based interactive media [4]. Learning technology can be used to solve various problems. It will certainly have a good impact on the learning process. Though the learning process will be better if it is support by the use of adequate media. Learners will interact directly with learning resources with the help of media that can lead to the achievement of the learning goals [5].

An interview with one of the biochemistry lecture at Department of Agrotechnology obtained information that biochemistry learning that occurred was still using the discussion method and PPT (PowerPoint). The media used by the teacher is simply PPT without videos and animation about carbohydrate material.

The development of an innovative learning media with multimedia lectora inspire integrated problem based learning 
is a strategy to provide good quality learning resources to be used in teaching and learning activities to improve students competence through their achievement. Lectora Inspire is a kind of Authoring Tools which are effective in creating learning media. Lectora is used to develop digital content of teaching materials and test material in the form of multimedia dynamic, easy (user friendly) and quality without the need for art design skills and graphic design and high programming to follow the changing dynamics of teaching and learning system. It is easy for teachers to make an assessment because it automatically scores or scores appear. The types of questions that can be made on lectora inspire, there are multiple choice questions, right-wrong questions, short stuffing questions, matching / matching questions, pull and place questions, and location determination questions [6]. Multimedia lectora inspire can improving students' achievement on acid-base material [6]. For the active role of students required the availability of teaching material that used student-centered learning model for example is model PBL (Problem Based Learning), a learning model that emphasizes need for students to investigate and build their own knowledge and have problem-solving skills [7]. The PBL refers to placing the student in complex and meaningful problem situation, solving the problems in the real life through the group cooperation, learning the knowledge hidden behind the problems, forming the ability to solve problems, and cultivating the students abilities from independent learning [8].

This research was conducted with two objectives: (1) to determine the eligibility of biochemical learning media with lectora inspire integrated problem based learning in the teaching of carbohydrate topic, and (2) to investigate differences in student achievement learned by using multimedia lectora inspire integrated problem based learning.

\section{METHODOLOGY OF RESEARCH}

\section{A. General Background}

This study was carried out in the Department of Agrotechnology, Universitas Medan Area (UMA). The research steps include developing multimedia for the Carbohydrate topic, standardization of the learning multimedia, and implementation of the developed learning multimedia to improve students' achievement.

\section{B. Population and Sample}

This study involved 60 second-semester students. The samples were totally selected and divided into two classes, which are referred to as the experimental class I (using the developed learning multimedia) and the experimental class II (using the learning media that used in Department of Agrotechnology). Sample in each class were made homogenous by rejecting outlier samples based on student ability to solve biochemical problems in the pre-test. Samples were all thread equally, 30 students per class were included in the data analysis.

\section{Instrument of Research}

This study uses test and non-test as instruments. The non-test instrument was a modification between SNPT and BSNP questionnaire integrated which were integrated with interactive computer media and Problem Based Learning. While the test instrument is essay questions which consisting of 10 questions relating to the Carbohydrate topic. Data were completely collected after the answer sheets have been assessed.

\section{RESULTS OF RESEARCH}

This learning multimedia was developed using the ADDIE model. It has 5 stages, namely analysis, design, development, implementation and evaluation. This study was conducted in two classes with different treatments where the experimental class I was taught using Lectora Inspire integrated Problem Based Learning and the experimental class II was taught using PowerPoint integrated Problem Based Learning.

\section{A. Analysis of Biochemical Learning Media in Program Study Agrotechnology}

The eligibility assessment of PowerPoint media was carried out descriptively using SNPT questionnaire which was integrated with interactive computer media and Problem Based Learning. The results analysis used based on the eligibility of the SNPT content in Table 1.

TABLE I. RESULTS OF ANALYSIS OF THE MEDIA POWERPOINT BASED ON ELIGIBILITY SNPT CONTENT

\begin{tabular}{|c|c|c|}
\hline \multirow{2}{*}{ Aspect } & \multicolumn{2}{|c|}{ Eligibility of SNPT Content } \\
\hline & Components & Description \\
\hline $\begin{array}{l}\text { Graduate } \\
\text { Competence } \\
\text { Standard }\end{array}$ & $\begin{array}{l}\text { - Learning outcomes of } \\
\text { appropriate attainment } \\
\text { from the course } \\
\text { - The purpose of learning } \\
\text { appropriate learning } \\
\text { outcomes } \\
\text { - Indicators of appropriate } \\
\text { learning objectives }\end{array}$ & $\begin{array}{l}\text { - Learning outcomes do } \\
\text { not match } \\
\text { - Learning objectives are } \\
\text { suitable } \\
\text { - Match indicator }\end{array}$ \\
\hline $\begin{array}{l}\text { Learning } \\
\text { Content } \\
\text { Standard }\end{array}$ & $\begin{array}{l}\text { - } \begin{array}{l}\text { The concept of } \\
\text { carbohydrate } \\
\text { matches topic } \\
\text { achievement of the } \\
\text { course }\end{array} \\
\text { - } \begin{array}{l}\text { The accuracy of the } \\
\text { material presented }\end{array} \\
\text { - Depth of material } \\
\text { - Experiments } \\
\text { examples and problem } \\
\text { in the corresponding } \\
\text { reality } \\
\text { - The accuracy of the } \\
\text { theory according to the } \\
\text { field of science } \\
\text { - Relevant and interesting } \\
\text { material and example }\end{array}$ & 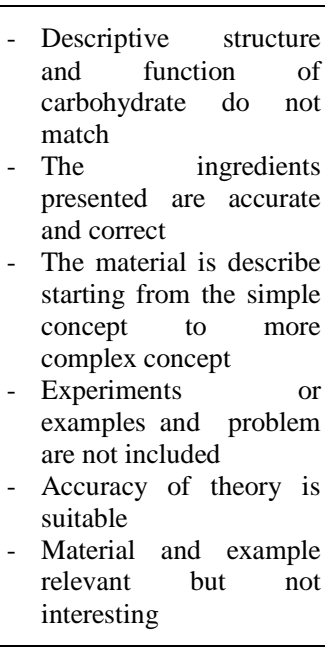 \\
\hline $\begin{array}{l}\text { Learning } \\
\text { Process } \\
\text { Standard }\end{array}$ & $\begin{array}{l}\text { - Encourage the growth of } \\
\text { coopertive } \\
\text { - Grow curiosity } \\
\text { - Student-centered }\end{array}$ & $\begin{array}{l}\text { - Media can't growth of } \\
\text { cooperative } \\
\text { - Media can't foster } \\
\text { curiosity } \\
\text { - The learning process is } \\
\text { still traditional }\end{array}$ \\
\hline
\end{tabular}

Based on the result, it showed that eligibility SNPT content is eligible to use but needs to be developed. Next, the 
results of the media analysis used based on the feligibility of the interactive computer media in Table 2.

TABLE II. RESULT OF ANALYSIS OF THE MEDIA POWERPOINT BASED ON ELIGIBLITY INTERACTIVE COMPUTER MEDIA

\begin{tabular}{|c|c|c|}
\hline \multirow{2}{*}{ Aspect } & \multicolumn{2}{|c|}{ Eligibility of Interactive Media Computer } \\
\hline & Component & Description \\
\hline Design & $\begin{array}{l}\text { - Icons / logos can help } \\
\text { users } \\
\text { - Complete menu } \\
\text { introduction about media, } \\
\text { menu learning materials, } \\
\text { etc.) } \\
\text { - Matches the design layout } \\
\text { with the target material } \\
\text { - Forms of interest in } \\
\text { symbol navigation }\end{array}$ & $\begin{array}{l}\text { - There is no icon / logo } \\
\text { - There is no menu about } \\
\text { media } \\
\text { - The layout of the design } \\
\text { with the target material } \\
\text { is not appropriate } \\
\text { - There is no symbol } \\
\text { navigation }\end{array}$ \\
\hline Audio & $\begin{array}{lll}\text { - } & \text { Suitable music } \\
\text { presentation } & \\
\text { - } & \text { Voice clarity } & \\
\end{array}$ & $\begin{array}{l}\text { - Do not use music } \\
\text { - Do not use video or } \\
\text { music }\end{array}$ \\
\hline Visual & $\begin{array}{l}\text { - Accordance to the color } \\
\text { proportion } \\
\text { - Choice of color and font } \\
\text { size on proportional front } \\
\text { cover } \\
\text { - Background selection is } \\
\text { appropriate } \\
\text { - Selection of the } \\
\text { appropriate font type }\end{array}$ & 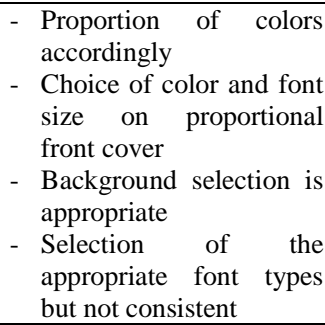 \\
\hline $\begin{array}{l}\text { Animatio } \\
\mathrm{n}\end{array}$ & 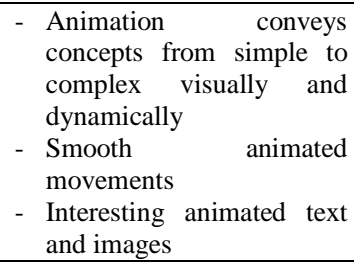 & $\begin{array}{l}\text { - No animation } \\
\text { - No animated text and } \\
\text { image }\end{array}$ \\
\hline Video & $\begin{array}{l}\text { - Animation conveys } \\
\text { concepts from simple to } \\
\text { complex visually and } \\
\text { dynamically }\end{array}$ & $\begin{array}{l}\text { - There are no learning } \\
\text { videos related to the } \\
\text { material }\end{array}$ \\
\hline $\begin{array}{l}\text { Media } \\
\text { Operation }\end{array}$ & $\begin{array}{l}\text { - Operating } \\
\text { compatibility }\end{array}$ & $\begin{array}{l}\text { - Easy to operate } \\
\text { - The media is less } \\
\text { creative and innovative } \\
\text { because it is only about } \\
\text { the material and there is } \\
\text { no video or animation } \\
\text { that can support learning } \\
\text { - This program does not } \\
\text { crash and the operating } \\
\text { system is easy } \\
\text { - The loading process is } \\
\text { not long } \\
\text { - Media is used to keep } \\
\text { abreast of knowledge but } \\
\text { not be used optimally }\end{array}$ \\
\hline
\end{tabular}

Based on research results, it appears that the eligibility of interactive computer media is eligible to use but needs to be developed in several aspects. Furthermore, the results of the media analysis used based on the eligibility of problem based learning in Table 3 , it shows that it is not eligible to use and needs to be developed in all aspects of problem based learning.
TABLE III. RESULT OF ANALYSIS OF PROBLEM BASED LEARNING MODEL

\begin{tabular}{|l|l|l|}
\hline \multirow{3}{*}{ Aspect } & \multicolumn{3}{|c|}{ Eligibility of PBL Model } \\
\cline { 2 - 3 } & $\begin{array}{l}|c| \\
\text { Cive problem orientation } \\
\text { to students }\end{array}$ & $\begin{array}{l}\text { Description } \\
\text { There is no problem orientation } \\
\text { on the media displayed. }\end{array}$ \\
\cline { 2 - 3 } Sintact & $\begin{array}{l}\text { The formulation of the } \\
\text { problem is in accordance } \\
\text { with the learning } \\
\text { outcomes }\end{array}$ & $\begin{array}{l}\text { There is no problem } \\
\text { formulation. }\end{array}$ \\
\cline { 2 - 3 } & $\begin{array}{l}\text { Stimulate student } \\
\text { curiosity to question and } \\
\text { seek answers to the } \\
\text { problems displayed }\end{array}$ & $\begin{array}{l}\text { There are no problems } \\
\text { displayed or exercises that can } \\
\text { be used to stimulate student } \\
\text { curiosity. }\end{array}$ \\
\cline { 2 - 3 } & $\begin{array}{l}\text { The ability to bring up } \\
\text { feedback for self- } \\
\text { evaluation }\end{array}$ & \begin{tabular}{l} 
There is no exercise \\
\hline
\end{tabular} \\
\hline
\end{tabular}

Based on Table 1; Table 2; and Table 3, the results of media analysis used in the Department of Agrotechnology have deficiencies in several aspects that need to be revised and developed.

\section{B. Standardized of Multimedia Lectora Inspire Integrated Problem Based Learning.}

The development of biochemistry learning multimedia has been standardized to make it available to students of the Department of Agrotechnology. Standardization was carried out by presenting a multimedia eligibility questionnaire on carbohydrate topics to the validator, namely biochemistry and chemistry courses.All experts responded positively to lectora multimedia learning that inspired integrated problem-based learning.

The learning package has met the requirements of the SNPT parameter standards regarding Graduates Competency Standards, Learning Content Standards, and Learning Process Standards presented in Figure 1; integrated problem-based eligibility is presented in Figure 2; and the eligibility of interactive computer media presented in Figure 3.

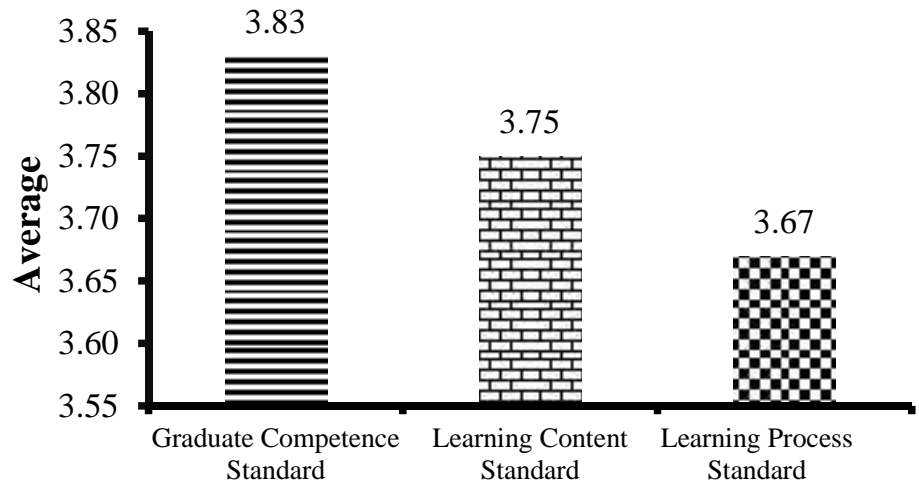

Aspects of Assessment

Fig 1. The avarage score for SNPT Parameters

The average eligibility of SNPT content aspect obtained value of 3.75 with category very eligible to use. 
TABLE IV. STUDENTSS' ACHIEVEMENTS ON CARBOHYDRATE TOPIC

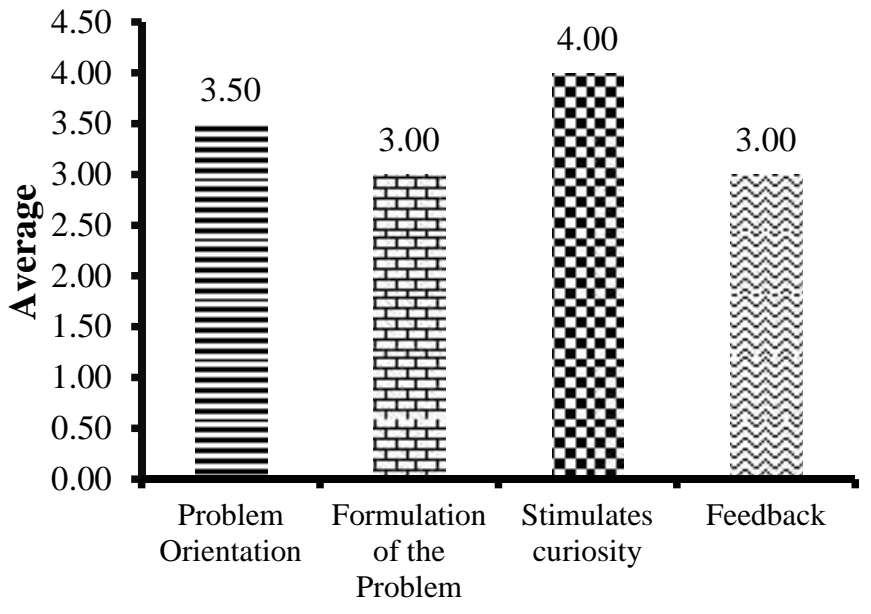

Aspects of Assessment

Fig 2. The avarage score for aspect of integrated PBL Model

The average eligibility of integrated problem based aspect obtained a value of 3.38 with the category very eligible to use.

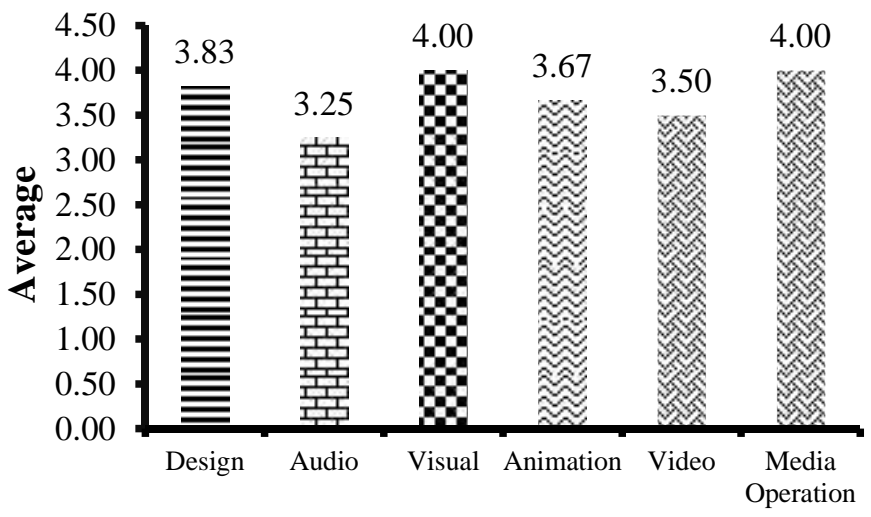

Aspects of Assessment

Fig 3. Avarage score for aspect of interactive computer media

The average eligibility of interactive computer media aspect obtained value of 3.48 with category very eligible to use.

\section{Implementation of Developed learning Multimedia Lectora Inspire Integrated Problem Based Learning.}

The developed learning package has been implemented as a teaching and learning multimedia Lectora Inspire integrated Problem Based Learning in the experimental class I, while PowerPoint learning media used in the experimental class II. Pre-tests are conducted for both classes before teaching and learning activities begin. After completing the learning session, students are given an evaluation test to measure their achievement on the carbohydrate topic as summarized in Table 3.

\begin{tabular}{|c|c|c|c|c|c|}
\hline \multirow{2}{*}{ Classes } & \multirow{2}{*}{$\begin{array}{c}\text { Stude } \\
\text { nts }\end{array}$} & Pre-Test & Post-Test & \multirow{2}{*}{ N-Gain } & \multirow{2}{*}{$\begin{array}{l}\text { Catego } \\
\text { ry }\end{array}$} \\
\hline & & Average & Average & & \\
\hline Experiment I & 30 & 30.53 & 81.77 & 0.74 & High \\
\hline Experiment II & 30 & 30.67 & 74.50 & 0.64 & $\begin{array}{l}\text { Mediu } \\
\text { m }\end{array}$ \\
\hline
\end{tabular}

The results showed that student achievement in the experimental class I was different from in the experimental class II. The results show that increasing student achievement with the use of multimedia Lectora Inspire integrated PBL as a source of learning in experimental class I. In addition, the effectiveness of learning because the use of multimedia lectora inspires integrated PBL in the experimental class I is higher than in the experimental class II. Furthermore, the results show that student achievement in biochemistry, especially on the topic of Carbohydrates, increases significantly due to the learning package developed.

\section{DISCUSSIONS}

Multimedia Lectora Inspire developed in this study has been designed integrated Problem Based Learning to improve student achievement. Research steps include the development of multimedia for the topic of carbohydrates, standardization of learning multimedia, and implementation of learning multimedia developed to improve student achievement.

The development of multimedia Lectora Inspire integrated Problem Based Learning to have a positive impact on the teaching and learning process, especially on improving student achievement. The first step in the development process is an analysis by conducting the necessary analysis, literature analysis, and previous media used in the Department of Agrotechnology. The second step is design, learning media developed using Lectora Inspire software. Multimedia Lectora Inspire integrated PBL have been standardized based on the opinions of lecturers as expert validators. All respondents gave positive responses to the biochemical learning media developed on the topic of carbohydrates that were assigned as excellent (see results in Fig. 1; Fig. 2; and Fig. 3). In addition, the effectiveness of learning because the use of multimedia Lectora Inspire integrated PBL in the experimental class I is different from the good experimental class II (see the results in Table. 3). 3). Furthermore, the results show that student achievement in biochemical, especially on the topic of Carbohydrates, increased significantly due to the learning package developed.

The multimedia has fulfilled the standard requirements of SNPT content the parameters modified interactive computer media and PBL model which are modified. The integration of learning media and multimedia to support the topic of chemistry, variations in sample problems and solutions for evaluating evaluation tests with key answers are also included in the learning material package [9]. Games in multimedia lectora that inspire can be used as an alternative when students are bored when solving problems. Game-based learning groups are significantly more interested, concentrated, and able to control learning [10]. Videos and animations in the multimedia lektora inspire students who are very helpful in 
understanding the material. Using this video in the course significantly enhances student learning and strengthens conceptual understanding for important basic concepts [11]. The development of biochemical teaching materials on the topic of carbohydrates integrated problem-based learning improves learning outcomes [7]. The contribution of learning media developed has helped guide students to learn about Carbohydrate topics. The availability of innovation in learning packages attracts students to become independent learners. However, it has been acknowledged that some students face some difficulties in learning with new learning approaches (integrated problem-based learning) because they prefer their old learning styles which are oriented towards lecturer learning. Learning innovation by using technology, such as web-based approach and Massive Open Online Courses (MOOCs), can enhance and facilitate student learning process from traditional classroom to student-centred learning [12]. Learning innovation can facilitate student to change traditional learning process and their skill.

\section{CONCLUSIONS}

The development of multimedia Lectora Inspire in Carbohydrates topic has been developed to meet the needs of undergraduate students. Multimedia Lectora Inspire integrated Problem Based Learning to give a positive response to the biochemical learning media developed on the topic of carbohydrates assigned as highly eligible. The multimedia Lectora Inspire that was developed helping students to learn Carbohydrates topic and makes study more enjoyable, resulting in increased student achievement. Integrated Problem Based Learning makes students tend to work together in discussions. The results revealed that the achievements of both students in the experimental class I were higher than in the experimental class II.

\section{REFERENCES}

[1] M. Situmorang, M. Sinaga, J. Purba, S.I. Daulay, M. Simorangkir, M. Sitorus, and A. Sudrajat, "Imlementation of innovative chemistry learning material with guided tasks to improve students' competence", Journal of Baltic Science Education, vol 17 (4), pp. 535-550, 2018.

[2] R.B. Kurniawan, M. Mujasam, I. Yusuf, and S.W. Widyaningsih, "Development of physic learning media based on lectora inspire software on the elasticity and hooke's law material in senir high school", Journal of Physic, vol 1157 (3), pp. 1-7, 2019.

[3] N.I, Simatupang, and M. Situmorang, "Innovation of senior high school chemistry textbook to improve students' achievement in chemistry," Proceeding of the $2^{\text {nd }}$ International Conference of the Indonesian Chemical Society 2013 October, 22-23 ${ }^{\text {th }} 2013$, pp. 44-52, Universitas Islam Indonesia, Yogyakarta, Indonesia.

[4] Rasim and W. Setiawan, "Development of instructional devices for information technology and technology-based learning", Jurnal Pendidikan TIK, vol 1(2), pp. 1-10, 2008.

[5] M.Liu, S.Liu, Z. Pan, W. Z, and C. Li, "Examining science learning and attitude by At-Risk student after they used a multimedia-enriched problem-based learning environment", Interdisciplinary Journal of Problem-Based Learning, vol 13 (1), pp. 1541-5015.

[6] W. fajrina, M. Simorangkir, and Nurfajriani, "Developing interactive computer based learning media of lectora inpire to enchance conceptual skills of senior high schools students", J. Advances in Social Science, Education and Humanities Research, vol 200, pp 57-60, 2018.

[7] Ersalinda, M. Simorangkir, and S. Saronom Silaban, "Development of biochemistry teaching material on carbohydrate through problem based learning model according to KKNI curriculum", Journal of Research \& Method in Education, vol 7 (4), 01-06, 2017.
[8] J. Li, and X. Wu, "Application of pbl in the multimedia teaching paltform of experiments on complete denture prosthodontics", Springer, pp 3-8.

[9] M. Situmorang, M. Sitorus, W. Hutabarat, and Z. Situmorang, "The development of innovative chmeistry learning material for bilingual senior high school students in Indonesia", International Education Studies, vol 8 (10), pp. 72-85, 2018.

[10] C.C. Chang, C. Liang, P.N. Chou, and G. Y. Lin, "Is game-based learning better in flow experience and various types of cognitive load than non-game-based learning? Perspective from multimedia and media richness", Computer in Human Behavior, vol 71, pp. 218-227.

[11] R. Ramachandran, E. M. Spack, and M.L. Fitzgerald, "Investigating the effectiveness of using application-based science education videos in a general chemistry lecture course", Journal of Chemical Education, vol 96 (3), pp. 479-485.

[12] Dagien , V., \& Gudonien , D, "The innovative methods for massive open online course design", Baltic Journal of Modern Computing,, vol 3 (3), pp. 205-213, 2015. 